\title{
Histone Deacetylase 1
}

National Cancer Institute

\section{Source}

National Cancer Institute. Histone Deacetylase 1. NCI Thesaurus. Code C19671.

Histone deacetylase 1 (482 aa, $\sim 55 \mathrm{kDa}$ ) is encoded by the human HDAC1 gene. This protein is involved in chromatin remodeling and the negative regulation of apoptosis. 